\title{
Lo que María Zambrano descubrió en su exilio caribeño
}

\author{
Roberta Johnson \\ (UCLA Y LA UNIVERSIDAD DE KANSAS) \\ rjohnson@ku.edu
}

(recibido xullo/2019, aceptado novembro/2019)

RESUMEN: Después de empezar su carrera filosófica bajo la tutela de José Ortega y Gasset en España, después de la Guerra Civil, María Zambrano se exilió en Cuba y Puerto Rico entre 1940 y 1953. Allí tomó contacto con el grupo poético "Orígenes" y escribió una serie de obras sobre mujeres, incluso "Eloísa o la existencia de la mujer" y "La tumba de Antígona", en las cuales desarrolla sus ideas sobre el alma y emplea uno de sus conceptos centrales "la razón poética".

PALABRAS CLAVE: María Zambrano, exilio, existencialismo, fenomenología, la razón poética,Cuba, Orígenes.

La vida y el pensamiento de María Zambrano fueron profundamente influenciados por su exilio de España durante 45 años después de que la Segunda República Española perdió la Guerra Civil (1936-1939) contra las fuerzas nacionalistas bajo el mando del General Francisco Franco. Zamabrano nació en Vélez-Málaga en Andalucía en 1904. Muy joven se trasladó con sus padres a Segovia más al norte, un traslado que consideraría su primer exilio. Sus padres eran maestros e intelectuales quienes le guiaron en su trayectoria de pensadora desde muy joven. Gracias a sus padres, en Segovia, Zambrano conoció al gran poeta filósofo Antonio Machado y empezó a leer la obra de Miguel de Unamuno. Cuando se fue a Madrid en los años 20 para estudiar en la Universidad, estaba rodeada de algunos de los escritores más destacados que España había visto en unos cien años -Ramón del Valle-Inclán, José Ortega y Gasset, Federico García Lorca, y Xavier Zubiriri- para nombrar solo unos cuantos. También en Madrid se juntó a un grupo de estudiantes que militaba por una república. 
A pesar de la brillante producción cultural de la primera parte del siglo veinte en España, en cuanto a la política el país no estaba estable porque el rey Alfonso XVIII dejó que un dictador militar asumiera el poder. Las obras tempranas de Zambrano -unos artículos publicados en El Liberal en1928 y su primer libro Horizonte del liberalismo de 1930- reflejan sus intereses políticos. Cuando estalló la Guerra Civil en el verano de 1936, amenazando acabar con su querida República, Zambrano dedicó toda su energía y su pluma a trabajar por el gobierno que había sido democráticamente elegido. Cuando sus esfuerzos y los de cientos de miles otros españoles fueron derrotados, Zambrano, como tantos republicanos militantes, se exilió en Latinoamérica. En 1939 Zambrano enseñó brevemente en México antes de pasar un período extendido en el Caribe (Cuba y Puerto Rico) entre 1940 y 1953 (interrumpido por una estancia de dos años en París (1946-1948). Después de 1953, Zambrano dejó el Caribe definitivamente para residir en Europa, primero en Roma y luego en Francia cerca de Suiza, hasta su vuelta a España en 1984. Muchas veces se considera el exilio político como una tragedia para los que lo experimentan, y no quisiera disminuir ese aspecto del exilio de Zambrano, pero el exilio era también una liberación personal y filosófica para la pensadora. En un famoso comentario que hizo Zambrano cuando volvió a España en los años 80 dijo "Amo mi exilio".

Y reflejando sobre su exilio muy al final de su vida, teorizó sobre la experiencia en un pequeño libro Los bienaventurados donde evoca las revelaciones que le proporcionó el exilio, lo cual considera un peregrinaje entre las entrañas esparcidas de la historia trágica:

Nudos múltiples, oscuridad y algo más grave: la identidad perdida que reclama rescate... Pues el exiliado es objeto de mirada antes que de conocimiento. Al objeto de conocimiento se contrapone el objeto de visión, que es tanto como decir de escándalo... Al propiamente refugiado, al únicamente refugiado, el destierro no le absorbe. Alguna ráfaga de sentimiento, o más bien de sentimentalidad que le hace asomar lágrimas a los ojos, un consuelo en la debilidad y hasta una especie de ofrenda aplacatoria a los Lares que a medida que abandona se jura mantener en alto siempre. Y se siente así más fiel a su tierra que nunca, más que nadie, más que los demás. Pues que la comparación se va apoderando de su mente y del inagotable cálculo que podríamos Ilamar 'existencial'. $(32,33,37)$

Si el estimulante ambiente cultural español en el cual Zambrano inició su carrera filosófica en los años veinte y treinta del siglo pasado fue acortado por el régimen franquista que severamente limitaba el pensamiento libre y creativo, Latinoamérica proveyó una continuación de y quizás hasta una ventajosa alternativa a su España nativa en los años cuarenta. Latinoamérica había asimilado las filosofías del fenomenólogo alemán Max Scheler, del ensayista y novelista Miguel de Unamuno y del profesor universitario y mentor de María Zambrano, José Ortega y Gasset. Las ideas de estos tres pensadores son importantes puntos de arranque para la filosofía de la propia Zambrano. Así que Latinoamérica le era filsóficamente familiar a Zambrano, pero que al mismo tiempo era geográfica y culturalmente diferente de España. En este ensayo exploro algunos aspectos 
claves de la filosofía zambraniana que se desarrollaron en el nuevo mundo como sus ideas sobre lo femenino y su concepto central de la razón poética.

En su libro Place and Placelessness [Lugar y el estado de estar sin lugar] Edward Relph emplea el término "un estar dentro existencial" para el sentido más profundo del sentido de lugar, una situación "in which a place is experienced without deliberate selfconscious reflection yet is full with significances" [en la cual un lugar se experimenta sin reflexión auto-consciente deliberada y aun así está lleno de significancias]. El estar dentro existencial es una emersión total y sin auto-conciencia de lugar. La persona y el ambiente (las circunstancias en términos orteguianos) están íntimamente unidos por los lazos de la familiaridad, la relación y una sensación de estar en casa. La persona es parte del lugar y el lugar es parte de la persona. Relph también describe la posición opuesta o "el estar fuera existencial", una situación en que la persona se siente alienada de un ambiente que no tiene sentido. Si el vivo ambiente cultural de España en el cual Zambano inició su carerra filosófica en los años veinte y treinta fue acortado por el filosóficamente desiértico regimen de Francisco Franco, Latinoamérica proporcionó una continuación de o hasta un mejoramiento sobre su España natal. Latinoamérica había absorbido las filosofías de Max Scheler, de Miguel de Unamuno y de José de Ortega y Gasset, quienes formaron la base de la filosofía temprana de Zambrano, mucho antes de que Zambrano llegara a Latinoamérica. Así que Latinoamérica le era familiar a Zambrano en términos filosóficos, aunque era muy diferente en términos geográficos y culturales. Según Relph la separación del lugar que caracteriza el estar fuera existencial "can foster a sense of alienation and threat for newcomers [while] it can generate a sense of freedom for others" (88) [puede fomentar una sensación de alienación y amenaza en los nuevos y puede generar una sensación de libertad en otros].

En Latinoamérica (específicamente en Cuba y Puerto Rico) Zambrano se descubrió a sí misma; encontró su propia voz intelectual, y reafirmó la idea central que guía la mayor parte de su filosofía -la importancia de incluir las emociones, lo que ella denomina el alma- en la descripción filosófica de ser. La razón poética, que discutiré abajo, es la solución zambraniana para incorporar las emociones en un esquema filosófico tradicional en el cual normalmente no están incluidas. Paradójicamente, entonces, Latinoamérica (y especialmente Cuba) liberó a Zambrano de su identificación con España como ser de dentro no consciente y la lanzó a un papel como ser de fuera auto-consciente, lo cual le permitió ir más allá de las nociones cívicas y sociales del ser para encontrar una posición más centrada en lo interno. Como escribió en Los bienaventurados:

De destierro en destierro, en cada uno de ellos el exiliado va muriendo, desposeyéndose. Y así se encamina, se reitera su salida del lugar inicial, de su patria y de cada posible patria, dejándose a veces la capa al huir de la seducción de una patria que se le ofrece, corriendo delante de su sombra tentadora; entonces inevitablemente es acusado de eso, de irse, de irse sin tener ni tan siquiera adónde. Pues que de lo que huye el prometido al exilio, marcado ya por él desde antes, es de un dónde, de un lugar que sea el suyo. Y puede quedarse tan solo allí donde pueda agonizar libremente, ir meciéndose al mar que se revive estar despierto sólo cuando el amor que le llena se lo permite, en soledad y libertad. (37-38) 
Habría que fijarse en el hecho de que en este pasaje cada vez que Zambrano emplea la palabra "destierro" (literalmente "desposeído de la tierra," y no "exilio") da una importancia al lugar físico. Tanto "destierro" como "exilio" Ilevan el sentido de estar fuera de la patria de uno por razones políticas, pero "destierro" Ileva otros sentidos como "tierra salvaje" o "tierra desiértica" que añaden otras dimensiones al exilio. "Destierro," que comprende la palabra "tierra" dentro de sí también Ileva el sentido material que no está presente en la palabra más conceptual "exilio." Esta posición de estar dentro y fuera, estar en un espacio liminal entre la conciencia no auto-reflectiva inherente en la posición de dentro y la posición de una persona de fuera puede haberle dado a Zambrano el conocimiento del alma y el ser que adquirió en sus años caribeños.

Antes de seguir con la idea madura que formula Zambrano sobre el alma, quisiera trazar el trasfondo del trabajo sobre el alma (o las pasiones) antes de su exilio en Cuba. Su trayectoria hacia una definición del alma empezó en 1934 cuando escribió "Hacia un saber sobre el alma".

En este ensayo, que postula un conocimiento por medio del corazón, se nota una gran influencia de Ordo Amoris, del fenómenologo alemán Max Scheler. Zambrano anota que el estudio del alma se había dejado a la psicología, que se acercó al alma con una lente científica. Según Zambrano, dada esta situación, el alma se volvió hacia la literatura. Para Zambrano la literatura, que lleva al alma (las emociones) en su seno, es el intermediario ideal entre el alma y el mundo porque participa tanto en las esferas públicas como las privadas. José Ortega y Gasset, el mentor de Zambrano en la Universidad de Madrid, criticó severamente "Hacia un saber sobre el alma", aunque publicó el ensayo en su prestigiosa Revista de Occidente. Ortega dijo que al saltar la idea occidental de la razón, Zambrano estaba intentando llegar muy lejos sin haber travesado todo el terreno intermediario. Esta crítica hizo llorar a Zambrano, quien salió del despacho de Ortega en lágrimas.

Una vez que estaba exiliada en México, Zambrano continuó desarrollando sus ideas sobre el lugar central del alma o las emociones en el pensar filosófico, y en México publicó Filosofía y poesía y Poesía y pensamiento en la vida Española. En estos libros Zambrano arguyó por "un nuevo conocimiento poético, filosófico e histórico," "un conocimiento de reconciliación." Buscaba "al poeta que entienda filosofía como la meta última de su poesía; el filósofo que no acepta la razón que se resigna a renunciar la belleza; el historiador que se siente penetrado por el tedio de las citas, la mezquindad de los hechos" (Pensamiento y poesía 266). Para Zambrano, el alma es la clave al proceso de llevar el reino de lo ético al sujeto individual, porque el alma se sitúa en el espacio central entre el ser y el exterior natural. Así que le da al alma una fisicalidad que recuerda los filósofos pre-socráticos y estoicos. También figura aquí la dicotomía entre el conocimiento pre-reflexivo y el conocimiento reflexivo. Como ya indiqué Max Scheler, una de las fuentes importantes de la Zambrano temprana, al lado de su profesor y mentor José Ortega y Gasset, enfatizaron la capacidad de reflexionar como cualidad que distingue a los seres humanos de los animales. Zambrano añade el alma a esta dicotomía interior/exterior como medio de unir estas dos entidades que Scheler y Ortega dividieron. 
La experiencia caribeña no era la inspiración para la razón poética, pero ayudó a Zambrano a profindizar su pensamiento sobre ello. Quizás la mención más temprana de la razón poética se encuentra en un discurso que pronunció Zambrano en Chile en 1937 cuando la Guerra Civil Española estaba consumiendo a España y Zambrano y su marido estaban intentando ganar apoyo para la República que parecía estar perdiendo la Guerra. En este discurso se notan las raíces apasionadas y personales de la razón poética; el discurso también señala el hecho de que Zambrano estaba entrando en el proceso de alejarse de la situación política de España y empezando a explorar el reino interior de las pasiones. Dirige sus palabras a los poetas chilenos desde "la madre España":

Y para que nazca esa nueva época, ese mundo justo, luminoso e infinitamente humano, se quiebra hoy su tierra amarilla, se queman sus finos olivos bajo la metralla, se trastorna su luz y su cielo y vienen abajo las altas torres, en pie por voluntades de siglos, campos de tragedia sus encinares y roquedas, sus empinadas sierras y sus pálidas llanuras. Llorad, sí, poetas hermanos sobre su tierra humeante de pólvera, caliente de sangre y helada de cadáveres; llorad por todo eso que desaparece -belleza única e irreconstructible- ametrallado, herido, derrumbado y pisoteado por cascos de caballos africanos y por ciego odio sin entrañas. Una iniquidad sin nombre se ha conjurado sobre nuestra madre España para aniquilar su fecunda maternidad y sustraer al mundo su fruto. No podrán lograrlo porque la realidad histórica tiene algo de invulnerable como la vida misma y el pueblo español que encarna hoy el punto más alto -más real- de la historia sabe no retroceder

...Y es con la poesía y con la palabra, es con la razón creadora y con la inteligencia activa en conjunción con esa sangre que corre a torrentes, como hay que forjar este Renacimiento del pueblo español que traerá un mundo nuevo para todos los pueblos. $(95-96)$

La intersección de la razón y el dolor, que coloca la emoción a la par de la razón y que Zambrano cree esencial para sobreponerse a la tragedia española, se encuentra en las raíces de la razón poética. Éste es el dolor que José Ortega y Gasset, centrado como estaba en la razón, no sufrió. Ortega volvió a España poco después de que la dictadura de Francisco Franco consolidó el poder (Zambrano nunca le perdonó por lo que ella consideró una traición de la República, pero su resistencia a la filosofía de Ortega era tanto filosófica como política y personal). Durante sus cuarenta años de exilio, que empezó dos años después de pronunciar el discurso en Chile, Zambrano siguió afinando el concepto de la razón poética, desafiando los conceptos orteguianos basados en la razón vital y la razón histórica.

Después de un semestre poco gratificante en la Universidad de Morelia en México, en 1940 Zambrano recibió invitaciones a unirse al Instituto de Altos Estudios, recientemente fundado en La Habana, y al Instituto de Investigaciones Científicas de la Universidad de La Habana. Zambrano aceptó estos puestos, aunque suponían dejar atrás a su marido en México donde él había establecido un negocio. Así que de varias maneras Cuba representaba una nueva vida para Zambrano. En La Habana recibió el respeto profesional y filosófico que la eludieron en España y en México. Además, Zambrano tenía la buena fortuna de que su llegada a Cuba en 1940 coincidiera con el auge de un grupo de jóvenes 
poetas conocido como Orígenes (nombre de la revista que producían). Este grupo llegó a ser uno de los movimientos poéticos mas importantes de Latinoamérica en el siglo veinte. Zambrano figuraba como una especie de gurú para el grupo que incluía a José Lezama Lima, a Cintio Vitier y a Virgilio Piñero, entre otros. Alguien ha dicho que Zambrano era la sacerdotisa de la vida intelectual cubana en los años veinte. Se ha dicho que tenia una presencia magnética, casi mágica y que podía hechizar a los que la escuchaban. La relación entre Zambrano y los poetas era recíproca. Ella no sólo estimulaba y animaba a los poetas; ellos a su vez proveían a Zambrano de un público de admiradores inteligentes y comprometidos.

Además del contacto importante con los poetas del grupo Orígenes, la geografía de la isla era un factor vital que se asomó a su pensamiento de una manera subliminal. Douglas Pocock, parafraseando Space and Place: The Perspective of Experience [El espacio y el lugar: La perspectiva de la experiencia] de Yi-Fu Tuan anota que "place provides an organizing concept for what is termed our immersion in, or interpenetration with, the world. With its experiential perspective and varied scale, place relates to an area which is bounded and has distinctive internal structure, to which meaning is attributed and which evokes an affective response" (17) [el lugar provee un concepto organizador para lo que se llama nuestra emersión en, o interpenetración con, el mundo. Con su perspectiva experiencial y escala variada, el lugar se refiere a un area que tiene límites y que tiene una estructura interna distintiva, a la cual se asigna un sentido y que evoca una reacción afectiva]. En un artículo titulado "La Cuba secreta" publicado en 1948 en la revista cubana Orígenes, Zambrano explica el significado que tenía para ella residir en la isla. En Cuba encontró su "patria prenatal"; sentía a Cuba poéticamente, no como calidad sino como sustancia, una sustancia visible y poética. La geografía y el clima de la isla recordaban a Zambrano su nativa Andalucía. Era una comprensión corporal y visual, que, para Zambrano, era también la clave a la poesía. En "La Cuba secreta" escribe

Como un secreto de un viejísimo ancestral amor, me hirió Cuba con su flecha ya un poco alejada [Zambrano y su marido pararon en La Habana unos días camino a Chile en 1937]. Amor tan primitivo que aún más que amor convendría llamar "apego". Carnal apego, temperatura, peso, correspondiente a la más íntima resistencia; respuesta física, y por tanto sagrada, a una sed largo tiempo contenida. No la imagen, no la viviente abstracción de la palma y su contorno, ni el modo de estar en el espacio de las personas y las cosas, sino su sombra, su peso secreto, su cifra de realidad, fue lo que me hizo creer recordar que la había ya vivido. Mas las imágenes no podían coincidir con aquellas vistas mientras aprendía a ver: la rama dorada del limonero a la caída de la tarde en el patio familiar... ("La Cuba secreta," María Zambrano en Orígenes 45).

Cuba, el país asociado con su ser pre-consciente, la liberó de su ser cívico que había ejercido en la España pre-republicana y republicana y que había lanzado a un estado antes de su trabajo histórico y político para la nación española. Era un lugar donde podía contemplar el reino interior, las emociones, aquella parte que había explorado de una manera tenativa en "Hacia un saber sobre el alma". Zambrano creía que al nacer nuestro ser y nuestro destino fueron marcados por el país en que nacimos: "El instante 
de nacimiento nos sella para siempre, marca nuestro ser y su destino en el mundo" ("La Cuba secreta" 46). Postula un estado anterior al nacimiento, "un estado de puro olvido, de puro estar yacentes sin imágenes; escueta realidad carnal con una ley ya formada; ley que Ilamaría de las resistencias y apetencias últimas" (ibid.). Ése es el estado que Zambrano experimenta en Cuba. El residir en Cuba liberó a Zambrano de las restricciones temporales y espaciales que había sentido en una España que requería su atención política. Cuba ofrecía la posibilidad de entrar en el tiempo ilimitado de los sueños. En Cuba inició un peregrinaje órfico que la llevó a sus entrañas más interiores. Ésa era su Cuba secreta. De hecho entendía la vida isleña en general como un viaje al interior, una teoría que postuló en un libro sobre Puerto Rico, titulado La isla de Puerto Rico. Este libro nos recuerda de nuevo la importancia de los poetas origenistas para Zambrano, puesto que Lezama Lima había tratado el tema de la insularidad en un estudio de 1938. Zambrano reconoce esta deuda en la dedicatoria a Lezama que escribió en el ejemplar de La isla de Puerto Rico que le dio al poeta.

En 1943 tres años después de establecerse en Cuba, Zambrano continuó su rechazo de la razón orteguiana (la razón vital y la razón histórica\}, que había iniciado en 1934 con "Hacia un saber sobre el alma" y los libros Filosofía y poesía y Poesía y pensamiento en la vida española, ambos de 1939, en un nuevo libro Confesión como género literario. Allí confronta la antipatía de Ortega por lo que consideraba el personalismo en el arte que articuló en su famoso ensayo La deshumanización del arte. En este ensayo Ortega propone que el arte y la vida deben mantenerse en esferas completamente separadas. Por su parte Zambrano ve en el género de la confesión una manera artística de saltar la brecha entre la razón y la vida. La confesión ofrece la posibilidad de llegar al reino interior del ser humano, que sostiene los sueños liberadores. El lenguaje poético, metafórico capta y revela este viaje al interior. En el artículo "Metáfora del corazón" que publicó en Orígenes en 1944, Zambrano vincula el viajar hacia el interior -un viaje que asocia con la vida isleña- al descenso a los inferos por medio de la metáfora poética. Zambrano define la metáfora no solo como una entidad poética sino como algo fundamental a la vida: "[E]s también la supervivencia de algo anterior al pensamiento, huella en un tiempo sagrado, y por tanto, una forma de continuidad con tiempos y mentaliades ya idos, cosa tan necesaria en una cultura racionalista" ("La metáfora del corazón," María Zambrano en Orígenes 4). Claro que desde sus días en Madrid, Zambrano conocía las ideas sobre el tiempo vivido de Henri Bergson y de Martin Heidegger, pero era en Cuba donde descubrió y experimentó personalmente el tiempo fluido e ilimitado.

En cuanto a la metáfora del corazón, Zambrano escribe que, comparado con el cerebro, que es el órgano del cuerpo asociado con la razón, el corazón es una víscera secreta (acordémonos que también hay una Cuba secreta, que vincula la metáfora del corazón a la isla). Como Cuba, el corazón es un lugar que, como vimos arriba produce la continuidad con tiempos y mentalidades ya idos. Al ahondar profundamente en la vida secreta del corazón, Zambrano encuentra que "la vida del corazón es su condición de oscura cavidad, de recinto hermético" (9). Así que el corazón es una entidad interior, física, encerrada y misteriosa que al mismo tiempo proyecta la luz del sentimiento y emoción 
fuera de sí. Zambrano descubrió la metáfora del corazón en los poetas de Orígenes. Creía que esta metáfora había eludido a los miembros de su propia generación española -los de la así llamada Generación del 27 como Pedro Salinas, Jorge Guillén, Federico García Lorca, o Rafael Alberti- para quienes el lenguaje y la metáfora habían adquirido un estatus sagrado.

Para Zambrano, aunque la poesía pura de la Generación del 27 había inventado más metáforas que nunca antes, ninguno de ellas era suficientemente fuerte como para captar la vida humana sin forma. Para que una metáfora sea adecuada, tiene que basarse en una cultura y representarla, como la metáfora del corazón. Eso es lo que Zambrano encontró en la poesía de los escritores cubanos asociados con la revista Orígenes. Cuba era el amor primitivo y más que amor, un vínculo carnal con su tempertura y peso que corresponden a la resistencia íntima. Es la respuesta física, una sed largamente suprimida. Igual que William Butler Yeats, Zambrano le da al corazón su situación en el espacio. Una de las metáforas de Yeats se concentra igualmente en lo físico: "foul rag and boneshop of the heart" [trapo horrible y tienda de huesos del corazón]. La misma familiaridad del corazón le sirve al propósito de Zambrano de un sitio físico universal de las emociones humanas que está intentando captar ontológica y epistemológicamente. Para Zambrano, Cuba era la poesía viva, la fundación poética de la vida, el secreto de nuestro ser en el mundo.

Además del importante desarrollo de sus ideas sobre el interior de la persona y su relación con el exterior que adelantó en Cuba, Zambrano afinó las ideas sobre la mujer que había iniciado en una serie de artículos sobre la mujer publicados en España en 1928. Durante su estancia en Cuba escribió una serie de artículos sobre la mujer, el artículo/ drama "Eloísa o la existencia de la mujer", y una reseña de Grandeza y servidumbre de la mujer de Gustavo Pittaluga, en los cuales teorizaba sobre la subjetividad de los géneros sexuales. Su pensamiento sobre la mujer dejó que Zambrano adelantara su pensamiento sobre el alma (las emociones) que ella asoció más con las mujeres que con los hombres. Las conferencias que dio en La Habana sobre la mujer están en sintonía con el feminismo de la diferencia que distingue radicalmente las diferencias entre los sexos. Siguiendo su habitual acercamiento histórico a los problemas ontológicos, Zambrano arguye que los hombres han ejercido un individualismo extremo que ha llevado al mundo a una situación de crisis, mientras que las mujeres no han adquirido todavía el estatus de individuo. Las características de la vida individual de las cuales no disfrutan las mujeres son la soledad y la libertad. Zambrano recurre a la idea de espíritu o de creación de Max Scheler para distinguir los hombres de las mujeres. Según Zambrano, los hombres crean (entran en la vida intelectual que objetiviza), mientras que las mujeres se quedan más cerca de la naturaleza y de allí nunca experimentan la terrible soledad metafísica de la cual nació la filosofía. Los hombres combinan el instinto crudo con el espíritu, y las mujeres son el alma cautiva y hermética.

En "Eloísa o la existencia de la mujer" (1945), Zambrano identifica a Eloísa como habiendo encontrado una manera de librarse del cautiverio tradicional de la mujer al mismo tiempo que continúa siendo alma, o el ser en el mundo específicamente femenino. Según Zambrano, Eloísa tenía la valentía de existir. De allí Zambrano encuentra una nueva 
relación entre el ser y el mundo. El ser que considera en esta obra es femenino; según Elena Laurenzi, "[e]s la cuestión de la existencia metafísica u ontológica, como se prefiera o sea necesario decir, de la mujer" (Laurenzi 92). Postula que hasta que apareciera Eloísa, sólo los hombres habían adquirido una presencia histórica, mientras que las mujeres estaban sumergidas en una existencia subterránea:

La Historia es una forma de objetividad, y por tanto de desprendimiento de la vida; es ya una cierta muerte como lo es toda forma de objetividad. La mujer ha rehusado o no puede alcanzarla; parece vivir identificándose con la realidad más misteriosa y reacia a ser declarada por el 'logos' en cualquiera de sus formas. Vida misteriosa de las entrañas, que se consume sin alcanzar la objetividad. (Laurenzi 93)

Según Zambrano, las mujeres siempre habían sido alma pura, hasta que Eloísa ejecutó la hazaña histórica de ganar la libertad sin dejar su alma. Eloísa evadió la imagen de la mujer como algo sin tiempo, sin historia: "Se escapa de la cárcel de la objetividad para vivir y ser sujeto de su pasión. Se atrevió a existir. ...Para Eloísa existir es ofrecerse... La pasión pura le ha dado identidad, ha sufrido la más terrible de las metamorfosis" (Laurenzi 100,107, 112). El modelo de Eloísa es todavía social en el que su existencia depende de su existencia en la historia, aunque Eloísa adquirió su estatus histórico por medio de sus pasiones interiores.

Delirio y destino, la obra cumbre de la estancia de Zambrano en Cuba, es una novela autobiográfica o una autobiografía novelada, y una de las pocas obras zambranianas más bien literarias, aunque toda su obra está escrita en un estilo que asociamos más con la literatura que con la filosofía. La obra es un ejemplo de la razón poética en acción. Zambrano escribió Delirio y destino en 1952 (aunque no se publicó hasta 1989, tres años antes de su muerte). La autobiografía novelada contiene un resumen de todas las ideas sobre las cuales Zambrano había estado meditando durante los 16 años que había estado en contacto con los países caribeñas. La obra combina la historia personal -la vida de María Zambrano en los años veinte- con la vida nacional- también de los años veinte cuando Zambrano se juntó con los que militaban por una república. Entrelazados con estos dos hilos histórico-biográficos hay reflexiones filosóficas y pasajes líricos. La autobiografía, la historia nacional, la filosofía y la poesía se mezclan sin costuras. El género de la obra no se puede determinar. Es una situación semejante a la de José Lezama Lima cuya poesía tiene muchos elementos narrativos y cuyas novelas contienen mucho lirismo.

Delirio y destino es también una novela filosófica en la línea de las de Miguel de Unamuno, de Albert Camus o de Jean Paul Sartre. Pero Zambrano se enfoca más que estos autores masculinos en el aspecto físico de la vida, un ser físico revelado en la palabra poética como la que se encuentra en los poetas de Orígenes y en la novela Paraíso de Lezama Lima. De hecho, "Adsum" [Yo estoy aquí], la expresión en latín con la cual Zambrano empieza y termina Delirio y destino, puede atribuirse directamente al grupo Orígenes. Cuando los origenistas le pidieron a Zambrano que les ayudara a hacer conocer su trabajo como merecía, la filósofa prometió que lo haría por medio de artículos en revistas prestigiosas de América y Europa. Pero Cintio Vitier le contestó que ellos eran de 
Cuba y que querían ser reconocidos allí. A esta expresión de nacionalismo, Zambrano, que ya no tenía patria, comentó que eso de ser de aquí le sonaba servil; este "aquí" era el lugar universal que ella había previsto en compañía de José Lezama Lima. El estar presente es desconectado de un lugar particular y llega ser el alma o las emociones que asocia con Lezama Lima, el lugar universal del exilio. La noción de delirio en la autobiografía novelada está muy relacionada con la razón poética y tiene muchas fuentes. Delirio es originario, de la misma manera que el concepto griego del alma es originario. Zambrano escribe en un ensayo sobre el novelista Benito Pérez Galdós que "En el principio era el delirio" (La España de Galdós 192). Es la vida cruda, sangrienta y apasionada que sale del interior más profundo de la persona, de las entrañas. La poesía es "embiaguez" o "delirio" que puede llegar a la vida y la lucidez (Obras reunidas 137). Todo eso hace que el infierno trabaje el doble representando la vida interior en general como una sensación de agonía.

En Delirio y destino Zambrano le dio forma física al acto de soñar por medio de la literatura. Un pueblo entero estaba soñando una nueva existencia bajo la Segunda República Española -un sueño colectivo. La tradición, más bien que una fuerza restrictiva, forja un camino al "olvido creativo" y los "sueños creativos" para forjar un futuro sobre el que no pesa ni es restringida por el pasado. Para Zambrano los sueños no son el ensayo de un pasado ya vivido como lo eran para Freud, sino más bien una oportunidad de crear el futuro. El soñar es la aurora de la conciencia y la posibilidad.

Para Zambrano, entonces, los años que precedieron a la República, los que narra en Delirio y destino eran el sueño creador de España; es el momento cuando España pareció estar en la frontera de un nuevo mundo europeo con un gobierno democrático. El destino limita pero el delirio es infinito y las dos funcionan simultáneamente. El destino de María Zambrano dictó que ella tenía que exiliarse de su país nativo y su destino la llevó a su país pre-natal -Cuba. En Cuba encontró unas circunstancias físicas, intelectuales y culturales en las cuales pudo madurarse como filósofa del delirio, del sueño, algo muy poco cultivado en la filosofía occidental. Estos hallazgos dieron lugar a las obras importantes de Zambrano escritos al volver a Europa a mediados de los años 50- El hombre y lo divino y El sueño creador, ambos publicados en 1955. Estos libros revelan el interés de Zambrano por la filosofía mística y oriental, un interés que, como en tantas otras cosas, compartió con José Lezama Lima. Hacia el final de su vida Zambrano pudo decir que Lezama Lima perteneció a su vida esencial y que era un encuentro sin comienzo ni fin. Es muy difícil imaginar que la filosofía de María Zambrano se hubiera desarrollado de la misma manera sin su exilio y residencia en "la Cuba secreta". Paradójicamente, Zambrano tuvo que ser desarraigada de su España nativa para descubrir en el nuevo mundo la importancia de la razón poética/ física para el conocimiento humano.

En 1953 Zambranno, ya a cargo de su hermana enferma, volvió permanentemente a Europa, primero a Roma y luego a Francia y Suiza. Las ideas sobre el ser y su relación con la sociedad que Zambrano desarrolló en su período caribeño abrieron paso para dos obras culminantes que escribió en Roma -El hombre y lo divino (1955) y Persona y democracia (1958). El hombre y lo divino vuelve a la distinción entre filosofía y poesía que le había preocupado a Zambrano durante su corta estancia en México en 1939. Aquí la filosofía 
(el logos) y la poesía (las emociones) se juntan por medio de la religión como sentimiento. Con un acercamiento histórico, el libro rastrea el papel de la religión en la vida humana, especialmente en sus orígenes con los dioses griegos- la condenación de Aristóteles de los pitagóricos- el superhombre y la muerte de Dios de Nietzsche, las ideas de Sartre sobre la nada, y las de de la Grecia Antigua sobre la piedad, las ruinas, el amor, la envidia, el futuro, los templos, y la muerte. El hombre y lo divino es una defensa razonada del delirio como estado originario. Al principio, según Zambrano, el ser humano se sentía visto sin poder ver, y así no se sentía libre. Postula lo sagrado como una realidad escondida que es anterior a las cosas. El delirio no cuestiona, pero la poesía, relacionada con lo sagrado, inicia la confrontación con lo no conocido cuando empieza a cuestionar. El cuestionar señala la aurora de la conciencia, y nace la filosofía.

En Persona y democracia Zambrano vuelve al ser cívico del cual se había distanciado después de 1940, pero incorpora las lecciones sobre el interior que había aprendido en los años caribeños. Persona y democracia distingue entre el individuo y la persona, que Zambrano considera como más que un individuo. La persona es el individuo dotado de la conciencia de sí mismo/a como un valor supremo. El ser humano de Zambrano es

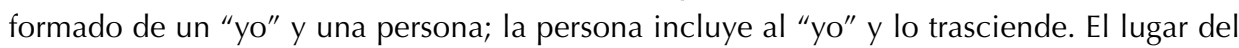
individuo se encuentra en la sociedad, pero el espacio de la persona es interior. Sintiéndose encerrado, una sensación de un "yo mismo" hermético e incomunicable es la condición esencial de la persona, aunque a veces él o ella quiere escaparse de aquel encerramiento y abrirse a un amigo, a un ser querido, o a la comunidad. Este equilibrio entre el interior y el exterior en la construcción del ser es lo opuesto de lo que Zambrano postuló en Horizonte del liberalismo, ya que ahora la persona interior es el lugar desde el cual la persona busca el exterior. Zambrano establece una dicotomía entre "persona" y "personaje" o "actor" (con máscara), que emerge cuando el ser humano se deja a sí mismo/a ser deformado/a por la historia. La teoría de Zambrano de la persona y su máscara intenta unir la visión interior con el exterior de la persona, entidad que siempre incluye una conciencia social (moral). Haciéndose eco de Albert Camus, dice que el reconocerse a uno mismo indica la aceptación de la culpa por haber dejado entrar la plaga en la ciudad; este autoreconocimiento promueve la cura de la comunidad. Para Zambrano, la libertad individual depende de la libertad de todos, porque todos los seres humanos se contienen en cada ser humano. Vivir como persona quiere decir estar consciente de no pesar sobre otros.

En 1967 Zambrano publicó una última obra sobre una figura femenina - La tumba de Antígona (como he anotado antes, la mayor parte de sus obras sobre lo femenino son del período cubano. Todavía residiendo en Cuba escribió una obra prelimiar sobre Antígona "Delirio de Antígona".) En las dos obras, Zambrano cambia radicalmente la versión de Sófocles de la historia. En la versión de Zambrano, Antígona no se suicida en su tumba; sigue viva y adquiere una voz significante que el dramaturgo griego le niega. Las dos versiones de Zambrano pueden ser interpretadas o de un modo filosófico o de un modo político, aunque la versión de 1967 desarrolla mucho más cada una de estas orientaciones. Antígona, cuya ropa clásica -la túnica- y papel político pueden entenderse como una alegoría de la Segunda República Española que seguía esperando la redención 
del fracaso en la Guerra Civil, a pesar de toda la evidencia contra tal esperanza. La Guerra Civil Griega entre los hermanos Eteolces y Polinices y el tirano Creonte pueden fácilmente leerse como la situación de España entre 1939 y 1967 (la Guerra Civil y la dictadura de Francisco Franco). En términos filosóficos Zambrano posiciona a Antígona en la aurora de la conciencia en un espacio profundo y sagrado interior (la tumba) y el luminoso exterior Ileno de plena conciencia de sí misma. Las imágenes de la luz y la oscuridad alternan mientras Antígona entra en diálogos con cada uno de los personajes del drama - su hermana Ismene, su madre locasta, su padre Edipo, sus hermanos Eteocles y Polinices, el Rey Creonte y la harpía. La conclusón del drama se deja abierta. Unos personajes anónimos se acercan a Antígona y la llevan fuera de la tumba hacia un futuro desconocido.

Durante la última etapa de su exilio en el campo francés, Zambrano escribió Claros del bosque (1977), la obra culminante y la más elusiva de su carrera filosófica. El título, que hace eco de la noción del Lichtung de Heidegger, sugiere que aquí Zambrano se vuelve a sus raíces fenomenológicas. para captar una experiencia intuitiva por medio de la metáfora. Claros del bosque empieza con una imagen física, el cuerpo sentiente al borde de un claro en el bosque, el ser físico en el espacio. Zambrano coloca al claro como un centro que vemos desde el borde. Un pájaro nos Ilama a que crucemos el espacio, y obedecemos, pero no encontramos nada, sólo un lugar que se abrió por un instante no repetible. El claro es un momento intuitivo en el cual el cuerpo sentiente, las emociones, y el pensamiento convergen y en el cual el conocimiento consciente y no consciente se juntan en un momento de reconocimiento. No sólo evoca Zambrano la intuición como un tema filosófico, sino también su método filosófico, que es analógico o metafórico, procediendo de una manera intuitiva más bien que racional. La intuición, sin embargo, no es sólo mental, sino también física (corporal). La sensación de revelación que podía ser un instante de recepción estética o un momento creativo. Zambrano reproduce la sensación cognitivo-emocional por medio de la metáfora, una cognición que es el reconocimiento que salva la brecha del claro del bloque en nuestro conocimiento.

En 1984 María Zambrano volvió a su España nativa, nueve años después de que el odiado dictador se había muerto. Aunque su obra no era muy conocida en la España de la época, ganó varios premios prestigiosos en su país nativo - el Premio Príncipe de Asturias (1981) y el Doctor Honoris Causa por la Universidad de Málaga (1983). En 1988 era la primera mujer que recibiera el Premio Cervantes. María Zambrano se murió en Madrid el 6 de febrero de 1991. Es difícil no ver su estancia caribeña de 1940 a 1953, justo a la mitad de su carrera filosófica, como la etapa en que Zambrano adquirió su voz propia gracias a su contacto con una geografía y un clima tan diferentes a los de España y una creación artística también más visceral como la del grupo Orígenes, abogando por un conocimiento que tenía en cuenta en cuerpo entero y no sólo el cerebro. 


\section{BIBLIOGRAFÍA}

Laurenzi, Elena (1995): María Zambrano. Nacer por sí misma, Madrid. horas y Horas.

Pocock, Douglas (1981): "Introduction", Humanistic Geography and Literature: Essays on the Experience of Place, Ed. Douglas C. D. Pocock, London, Croom Helm and Totowa, New Jersey, Barnes \& Noble Books.

Tuan, Yi-Fu (1977): Space and Place: The Perspective of Experience, Minneapolis, U Minnesota P.

Zambrano, María (1930): Horizonte del liberalismo, Madrid, Morato. (1930): Pensamiento y poesía en la vida Española, México, Casa de España.

$13-23$. (1934): "Hacia un saber sobre el alma", Revista de Occidente, núm. 46, pp.

(1939): Filosofía y poesía, Morelia, México, Publicaciones de la Universidad de Michoacana, Moreliz. . (1939) Michoacan, Morelia. (ortografía de Michoacan). (1944): "La metáfora del corazón", Orígenes, núm. 1, pp. 41-49. (1945): "Eloísa o a existencia de la mujer", Sur, núm. 14, pp. 35-38. (1948): "La cuba secreta", Orígenes, núm. 5, pp. 12-15. (1948): "Delirio de Antígona", Orígenes, núm. 5, pp. 14-21. (1955): El hombre y lo divino, México, F. C. E. (1958): Persona y democracia, San Juan de Puerto Rico, Departamento de Instrucción Pública. (1967): La tumba de Antígona, México, Siglo XXI. (1971): Obras reunidas, Madrid, Aguilar. (1977): Claros del bosque, Barcelona, Seix Barral. (1989): Delirio y destino, Mondadori. (1990): Los bienaventurados, Madrid, Siruela. (1995): La confesión: género literario y método, Madrid, Siruela. (1996): "A los poetas chilenos de "Madre España»", Antología España.1936, Ed. Hernán Soto, Santiago de Chile, Lom Ediciones, pp. 95-86. 